\title{
Role of Shri Kshetra Dharmasthala Rural Development Project (SKDRDP) in Micro Finance Through SHGs -A Study in Shimoga District of Karnataka
}

\author{
Eswar kumar belli.$S^{1}$, Dr.T.S Raghvendra ${ }^{2}$ \\ 1. Research Scholar, Department of Economics, L.B and SBS College (Autonomous) Sagar, Kuvempu \\ University-577401, Karnataka, India. \\ 2. Associate Professor,Department of Economics, L.B and SBS College (Autonomous) Sagar,Kuvempu \\ University-577401, Karnataka, India.
}

\begin{abstract}
Shri Kshetra Dharmasthala Rural Development Project (SKDRDP) played a vital role in rural reconstruction, agricultural Development, community development and rural development even during last three decades era in Karnataka state. After the introduction of microfinance through Self-Help Groups (SHG), they penetrated into each and every corner in India and actually the NGOs are responsible for converting the pilot project of microfinance into a major programme and the NGOs are responsible for making the microfinance through SHG as the largest programme in the world. This paper analyses the role of SKDRDP in sustainable rural development through microfinance. The study reported that SKDRDP are playing vital role in the formation of SHGs and motivating women to join the groups and linking the groups with the banks for microfinance. But, SKDRDP played limited role in marketing the products of SHGs.
\end{abstract}

Keywords: Micro finance, Self-Help Group, Rural development.

\section{Introduction:}

Shri Kshetra Dharmasthala Rural Development Project is committed for the upliftment of poor, marginalised, under privileged, impoverished and downtrodden and they are close and accessible to their target groups. SKDRDP are flexible in their operation, independent in its functioning, quick in decision making, people concerned, driven by social values and humanitarian principles. NGOs have their origin in non profit valuebased voluntary organisations and have been working throughout the world for centuries, particularly in the developed countries of the North (Khandakar and Danopoulos 2004). The voluntary sector has contributed significantly in reducing poverty, deprivation, discrimination and exclusion through awareness, social mobilisation, service delivery and training. They are the effective non- political link between Governments and people. SKDRDP are playing a vital role in the formation of Self-Help Groups and motivating women to join in Self-Help Groups. The Shri Ksherta Dharmasthala Rural Development Project encompasses all aspects of enriching the rural life. It is currently engaged in developmental activities in Dakshina Kannada, Udupi, Uttara Kannada, Coorg, Shimoga, Chickmagalur, Dharwad, Haveri, Gadag, Tumkur, Belgaum , Mysore, Chamarajnagar, Koppal, Davangere, Chitradurga districts operating in 20,000 villages covering more than $27,18,000$ families. SKDRDP is active with its community Development Programs throughout the state of Karnataka and holds its presence in six coastal towns under the Karnataka Urban Development and Coastal Environment Management Project. During the current year SKDRDP has extended its area of operation to six more districts viz., Hassan, Mandya, Bangalore Rural, Bellary, Raichur and Bagalkote.

The SKDRDP are expected to support the SHGs in the following aspects:

- to motivate the rural people to organize themselves and to form into SHG;

- to educate, train the group members in managing the group activities like maintenance of books of Accounts, conducting meetings, management of funds, etc;

- to inculcate, promote thrift and savings habit among the group members and to help in institution

- building along with the development of individual;

- to help the SHG in identifying raw materials and local resources;

- to help the group members to upgrade their skills and technology to make best use of resources;

- to make available credit facilities and to act as a link between the rural poor and the bank;

- to educate and train the group members to utilize credit properly and to improve their economic Conditions;

- to help the group members in exploring markets for their products;

- to work as facilitator in the meetings of the SHG; and

- to act as friend, philosopher and guide to the SHGs. 
This article brings out the role played by SKDRDP in delivery of micro finance through SHGs in sustainable rural development.

\section{Review Of Literature:}

Role of NGOs in micro finance and sustainable rural development were addressed by researches and some important studies are reviewed below.

NGOs developed a sense of leadership, organisational skill, management of various activities of a business,right from acquiring finance, identifying raw material, market and suitable diversification (Manimekalai and Rajeshwari 2001). The members of SHGs promoted by NGOs had gained almost twice the number of'employment days,' when compared to the members of SHGs promoted by banks (Harper 2002). Non -governmental Organisations organise and promote the SHGs with the objectives of inculcating Self-Help attitude among women and developing leadership (Joel 2003).Non-governmental Organisations as well as Voluntary Associations are actively involved in the formation and promotion of collectives of poor women known as Self-Help Groups throughout the State of Kerala (Loyola 2004). NGOs are promoting the SHG mechanism and linking it to various other development interventions (NCW 2004). NGOs play a vital role in educating rural women for rural development (Sarojini 2004). NGOs have inculcated the culture of savings and repayment strengthened the SHGs (Priya and Srivastava (2005). The role of NGO is critical in providing women with tools to improve their livelihood and enhance their self-development, teaches women the key areas of mobilisation, self awareness, capacity building and leadership development (Moyle, Dollard and Biswas 2006). NGOs playeda crucial role in the spread of micro finance and their success in delivering micro finance has made many of them to explore the possibility of scaling up their operations further (Shylendra 2007). NGOs are promoting SHGs and create confidence among financial institutions for establishing a lending relationship with the groups(Thirunarayanasamy and Thirumaran 2007). NGOs are playing a vital role in group formation and in monitoring and mobilising resources (Ramachandran 2007). SHG programme in Karnataka was largely through the initiatives of the NGOs (Sinha 2007). Bihar SHG movement indicates that it is the NGOs that took active role in the movement from the beginning (APMAS 2009). NGOs help in formation and nurturing of SHGs and training and capacity building requirements of SHGs are attended by NGOs (Thakur and Tiwari ). There are also some strong criticisms about the role of NGOs, which are given below. NGOs' role in reaching the poorest is limited and most of the income generating activities facilitated and promoted bythe NGOs generate income which forms only a small proportion to the total income of the family members (Laxmi and Archana 2005). NGOs are no panacea for all the ills impairing the development process (Ghosh 2005). NGOs are not effective in dealing with poverty, illiteracy and empowering the poor and NGOs are not alternative to the state; they can only complement the activities of the state (Ahmad 2006).

\section{Statement Of The Problem:}

The above studies have narrated the role of SKDRDP in delivering microfinance through SHGs. The present study was undertaken in Shimoga district of Karnataka to assess the role of SKDRDP in microfinance. The present study is undertaken with the following specific objective:

- To evaluate the role of SKDRDP in microfinance.

\subsection{SELECTION OF THE DISTRICT:}

\section{Research Methodology:}

There are 30 revenue districts in Karnataka. SKDRDP is currently engaged in developmental activities in 22 districts as on 31.3.2013 and 213788 Self Help Groups are functioning in the State. Very few studies were attempted in general about the district and in particular, studies related to effectiveness of micro finance in Shimoga district are almost non-existent. Shimoga district has 20041 SHGs as on 31.03.2013, As far as the state scenario is concerned; only limited studies have been conducted. The socio economic conditions of Shimoga district are similar to those of the neighboring districts such as Chickmaglore and Davangere. So the study outcome of Shimoga district might be useful for policy implications to other districts in the zone also. Questionnaire was prepared based on the issues and gaps in the studies carried out by the earlier researchers in India relating to the role of NGOs. Questionnaire contained closed and open ended questions and the questionnaire were prepared in English and translated into Kannada which was used to secure information systematically from the respondents.

\subsection{SAMPLING DESIGN:}

A three stage sampling procedure was adopted. Shimoga district in Karnataka was selected based on the number of SHGs in the state of Karnataka. In the second stage, two blocks in Shimoga district were selected which are having the average number of SHGs in the district, out of the 7 blocks in the district. Accordingly Shimoga and Bhadravathi blocks which are located at opposite ends of the district were selected. List of SHGs 
in these two blocks were obtained from the Project Officer of SKDRDP, Shimoga. The SHGs were selected randomly in the two blocks at 10 SHGs from each block.

\subsection{SELECTION OF RESPONDENTS:}

10 Self-Help Groups were identified from each block and 5 members from each SHG were selected randomly and in total 100 sample respondents comprising 50 respondents from Shimoga block and 100 from had Bhadravathi block, were selected for study were chosen for the study. The study was carried out during 2012-13. Groups formed in the last five years were studied. Members of the groups were interviewed with the pre-tested and well structured questionnaire/schedule.

\section{Profile Of The Respondents:}

\subsection{AGE OF THE RESPONDENTS:}

Table 1: Shows the Age Wise Distribution of the Respondents

\begin{tabular}{|c|l|c|c|}
\hline $\begin{array}{c}\text { S. } \\
\text { No. }\end{array}$ & \multicolumn{1}{|c|}{ Age } & Frequency & Per cent\% \\
\hline 1 & Less than 25 years & 13 & 13 \\
\hline 2 & 26 to 30 years & 24 & 24 \\
\hline 3 & 31 to 35 years & 20 & 20 \\
\hline 4 & 36 to 40 years & 19 & 19 \\
\hline 5 & 41 to 50 years & 20 & 20 \\
\hline 6 & Above 51 years & 04 & 4 \\
\hline & Total & $\mathbf{1 0 0}$ & $\mathbf{1 0 0}$ \\
\hline
\end{tabular}

Source: Primary data

The table 1 shows that respondents aged 51 years and above constitute a very low percentage of Self-Help Group members and majority of the respondents are within the age of 40 years.

\subsection{EDUCATIONAL STATUS:}

Table 2 : Indicates the Education Level of the Respondents

\begin{tabular}{|l|l|c|c|}
\hline S. No & \multicolumn{1}{|c|}{ Details } & Frequency & Per cent \% \\
\hline 1 & Illiterate & 24 & 24 \\
\hline 2 & Up to S.S.L.C & 69 & 69 \\
\hline 3 & P U C & 5 & 5 \\
\hline 4 & Degree & 2 & 2 \\
\hline & Total & $\mathbf{1 0 0}$ & $\mathbf{1 0 0}$ \\
\hline
\end{tabular}

Source: Primary data

The table 2 shows that most of the respondents (69\%) have studied up to 10th standard and two respondents $(2 \%)$ are graduates and 24 respondents are illiterate.

\subsection{FORMATION OF SELF-HELP GROUP:}

Generally SHGs are formed with the help of NGOs, Government departments, banks, neighboring SHG members, relatives and interested women. Sometimes a combination of the factors also helps in the formation of SHGs. Following table explains the opinions of the respondents about who helped in the formation of SHG.

Table 3: Help to Formation of Self- Help Group

\begin{tabular}{|l|l|c|c|}
\hline S. No & \multicolumn{1}{|c|}{ Opinions } & Frequency & Percent \\
\hline 1 & Bank & 04 & 4 \\
\hline 2 & NGO & 52 & 52 \\
\hline 3 & Govt. department & 10 & 10 \\
\hline 4 & Neighbour SHG & 14 & 14 \\
\hline 5 & Own interest & 1 & 1 \\
\hline 6 & Relatives & 1 & 0 \\
\hline 7 & Neighbours & 0 & 1 \\
\hline 8 & Bank \&NGO & 1 & 2 \\
\hline 9 & Bank \& Government department & 2 & 1 \\
\hline 10 & NGO \& Government department & 1 & 0 \\
\hline 11 & NGO \&Neighbouring SHGs & 0 & 1 \\
\hline 12 & NGO \& Own Interest & 1 & 1 \\
\hline 13 & NGO \& Relatives & 1 & 12 \\
\hline 14 & NGO \&Neighbours & 12 & $\mathbf{1 0 0}$ \\
\hline & Total & $\mathbf{1 0 0}$ & \\
\hline
\end{tabular}




\section{Source: Primary data}

It is evident from the table 4 nearly $52 \%$ of the respondents informed that Non-governmental Organisations helped women to form Self-Help Groups and own interest of women is another main factor for the formation of Self-Help Groups. Government departments played very negligible role in the formation of Self-Help Groups. It is inferred that NGOs played a vital role in the formation of SHGs.

\subsection{REASONS FOR JOINING SELF-HELP GROUP:}

One third of the respondents joined Self-Help Groups for the purpose of savings and $20 \%$ of respondents joined SHGs to supplement their family income and 10\% of respondents joined in groups to save as well as to avail loans. It is worthwhile to mention that only 10 respondents joined Self-Help Groups exclusively to start income generating activities. Some of the respondents have multiple reasons to join the groups and very few joined to gain special status and to get subsidy from banks.

Table 4: Explains the Reasons for Joining the SHGs

\begin{tabular}{|l|l|c|c|}
\hline S. No & \multicolumn{1}{|c|}{ Reasons } & Frequency & Percent \\
\hline 1 & To save & 33 & 33 \\
\hline 2 & To avail loan & 10 & 10 \\
\hline 3 & To start IGA & 10 & 10 \\
\hline 4 & Employment opportunity & 1 & 1 \\
\hline 5 & Social status & 1 & 1 \\
\hline 6 & Subsidy & 3 & 1 \\
\hline 7 & Neighbour's pressure & 1 & 20 \\
\hline 8 & Supplement family income & 20 & 0 \\
\hline 9 & To meet unexpected cash demand & 0 & 12 \\
\hline 10 & Save \& Loan & 12 & 7 \\
\hline 11 & Save \& IGA & 7 & 1 \\
\hline 12 & Save \& employment & 1 & 1 \\
\hline 13 & Save \& social status & $\mathbf{1 0 0}$ & $\mathbf{1 0 0}$ \\
\hline 14 & Total & & \\
\hline
\end{tabular}

\section{Source: Primary data}

\subsection{LOAN AMOUNT:}

The main objective of SHG micro finance programme is to ensure availability of credit through formal banking system. Most of the respondents received loans more than Ten thousands and less than Twenty five thousands and $88 \%$ of respondents received loans less than fifty thousands. Only 3 respondents out of 100 respondents received more than INR one hundred and fifty thousand as loan. 4 respondents did not obtain any loan from banks and the table 7 explains the quantum of microfinance loans received by the respondents.

Table 5: Loan Amount

\begin{tabular}{|l|l|c|c|}
\hline S.No & Loan Amount (INR) & Frequency & Per cent \\
\hline $\mathbf{1}$ & Up to 5,000 & 16 & 16 \\
\hline $\mathbf{2}$ & 5,001 to 9,999 & 21 & 21 \\
\hline $\mathbf{3}$ & 10,000 to 24,999 & 44 & 44 \\
\hline $\mathbf{4}$ & 25,000 to 50,000 & 7 & 7 \\
\hline $\mathbf{5}$ & 50,001 to $1,00,000$ & 5 & 3 \\
\hline $\mathbf{6}$ & Above $1,50,000$ & 3 & 4 \\
\hline $\mathbf{7}$ & No loan & 4 & $\mathbf{1 0 0}$ \\
\hline & Total & $\mathbf{1 0 0}$ & \\
\hline
\end{tabular}

Source: Primary data

From the table 5 , it is evident that $16 \%$ of the respondents received only INR. fivethousands as microfinanceand totally $81 \%$ respondents received microfinance loan up to INR twenty five thousands.

\subsection{PURPOSE OF LOAN:}

The study reported that $72 \%$ of the respondents used loans to start income generating activities/micro Enterprises; 24 respondents used loan for consumption purposes and 4 respondents did not get any loan fromJournal of Arts, Science \& Commerce the banks. The study reported that 4 respondents started provision or petty shops; 18 respondents micro business in the form of selling vegetables, milk, coconut, cattle feed, cut piece and sandy sales. 7respondents started service activities such as renting of utensils and cable T.V; 7 respondents started production and sale of pickles and candles. 
Table 6: Explains the Purpose of Lone

\begin{tabular}{|l|l|c|c|}
\hline S.No & Purpose of loan & Frequency & Per cent \\
\hline $\mathbf{1}$ & Animal husbandry (Sheep, Milch animals, Poultry) & 22 & 22 \\
\hline $\mathbf{2}$ & $\begin{array}{l}\text { Consumption expenses (Medical expenses, Children } \\
\text { education) }\end{array}$ & 24 & 24 \\
\hline $\mathbf{3}$ & Traditional activities (Agriculture, handlooms) & 14 & 14 \\
\hline $\mathbf{4}$ & Services (Cable T.V, suppliers, tailoring) & 7 & 7 \\
\hline $\mathbf{5}$ & $\begin{array}{l}\text { Micro and small business (Cut piece sales Cattle feed sales, } \\
\text { Construction materials sales, Small business (cart sales) } \\
\text { Sandy sales etc) }\end{array}$ & 18 & $\mathbf{4}$ \\
\hline $\mathbf{6}$ & Provision shops & 4 & 7 \\
\hline $\mathbf{7}$ & $\begin{array}{l}\text { Manufacturing and sales (pickles,agarbathi, } \\
\text { candles) }\end{array}$ & 7 & 4 \\
\hline $\mathbf{8}$ & No bank loan & 4 & $\mathbf{1 0 0}$ \\
\hline & Total & $\mathbf{1 0 0}$ & \\
\hline
\end{tabular}

Source: Primary data

\section{Role Of SKDRDP:}

SKDRDP Progenies training programmes for the Income Generating Activities (IGA) and they properly guide the members to start or establish IGA. 52\% of respondents expressed that SKDRDP organized training programmes relating to IGA, 55\% of respondents informed that SKDRDP guided them to start income generating activities. SKDRDP arranged exposure visits so that the SHG members get an impressive idea about the feasibility of starting income generating activities 50\%of respondents felt that SKDRDP arranged exposure and $40 \%$ of respondents expressed favorably that SKDRDP arranged for marketing of products. SKDRDP are expected to organise exhibitions so that the public have a chance to know about the products of Self-Help Groups and it paves way for marketing the products. It is however evident from the study that SKDRDP are not effective in organising exhibitions for marketing the products of micro enterprises.

SKDRDP is presently working with 27,17,875 families. For their convenience 2, 37,003 Self Help Groups have been promoted. These members contribute loan margins, borrow money, share it among themselves and repay at weekly intervals. In order to meet the financial need of the members, SKDRDP has borrowed funds from commercial banks and disbursed to the SHGs for onward lending to the members. During the current year Rs. 385.88 cores were disbursed to the SHGs. As on March 31, 2013 the micro finance outstanding is Rs. 2,593.00 cores. During the current year SKDRDP borrowed Rs. 1429.00 cores from commercial banks to sustain its micro finance operations. In spite of increased financial costs, SKDRDP did not revise its lending rates which were maintained at $18 \%$ on reducing scales or $10 \%$ on flat basis for loans. SKDRDP received subsidized loans for housing and small enterprise from NABARD and DBCDC. The interest subsidy was passed on to the beneficiary.

SKDRDP initiated a micro-financing scheme known as Pragathinidhi in 1996, which provides loans to members to help promote their livelihoods or develop infrastructure. The main features of Pragathinidhi include the provision of adequate funds without any administrative formalities, a convenient tenure, easy accessibility and easy weekly repayment installments. The funds required for lending are sourced from bank loans or the savings of the members which are deposited with the group's account. In 2003, with plans to extend Pragathinidhi on a larger scale, SKDRDP reinvigorated the program with systematic procedures. The group can now take loans for agricultural purposes, infrastructure development, non-formal sector development activities and group enterprises.

Table7: No. of loans availed by the members for various purposes under micro-credit:

\begin{tabular}{|c|c|c|}
\hline Purpose & No. of loans 2013-14 & Since inception \\
\hline Agricultural Development Program & 26,049 & $7,06,224$ \\
\hline Irrigation Program & 5,888 & $1,80,210$ \\
\hline Housing and Sanitation & 39,061 & $9,63,839$ \\
\hline Self Employment & 16,838 & $5,55,022$ \\
\hline Other Programs & 74,615 & $25,20,388$ \\
\hline Total & $1,62,451$ & $49,25,683$ \\
\hline
\end{tabular}

Source: SKDRDP Report

\section{Findings Of The Study:}

1. Majority of the respondents is less than 40 years of age (76 respondents out of 100) and 24respondents were beyond 40 years. Most of the respondents (59\%) have studied up to S.S.L.C, while2 respondents (2\%) are 
graduates. One third of the respondents joined Self-Help Groups for the purpose of savings and $20 \%$ of respondents joined to supplement their family income and $8 \%$ of respondents joined the groups to save as well as to avail loans. It is worthwhile to mention that only 17respondents joined Self-Help Groups exclusively to start income generating activities. Some of the respondents have multiple reasons to join the groups and very few joined to gain special status and to get subsidy from banks. 16 respondents (16\%) received loans less than INR five thousands and $88 \%$ of the respondents received loans less than INR fifty thousands. Only 3 respondents out of 100 respondents received more than one hundred thousand as loan. Only $24 \%$ respondents used loans for consumption purposes and remaining respondents used loans for production purposes.

2. NGOs remain as the largest single motivating force for group initiation and formation process as per the views of 52 respondents; Banks and Government departments played minimal role in motivating the Women to join in SHGs

3. More than fifty per cent of the respondents expressed that they were motivated to join in the groups by the NGOs. Banks and Government departments played minimal role in motivating the women to join in SHGs. The present study concludes that NGOs remain as the largest single motivating force for group initiation and formation process and Government departments, neighbors, relatives of women play negligible role in the formation of SHGs. Most of the respondents expressed that they were motivated to join in the groups by the NGOs. Banks and Government departments played minimal role in motivating the women to join in SHGs.

4. SKDRDP play an important role in SHG formation, linking the groups with the banks, arranging for loans and imparting training to start income generating activities.

5. NGOs are playing very little role in arranging for marketing activities, subsidy from DRDA and exhibitions. There is no doubt that the SHG mechanism increases the savings habit and enhances the income of the family so as to enable them to meet the daily domestic responsibilities.

6. Education of the respondents, period of membership in the SHG and loan amount significantly influences the awareness about the role and impact of SKDRDP.

\section{Suggestions:}

The SKDRDP should play a key role in arranging exposure visits to other successful SHGs, tie up for marketing, arranging exhibitions for the products of SHGs, if proper marketing arrangements are not provided the members of SHGs may lose their motivation and the sustainability of the micro enterprises may be affected in the long run. The SKDRDP should play a key role in arranging exposure visits to other successful SHGs, tie up for marketing and arranging exhibitions for the products of SHGs, if proper marketing arrangements are not provided the members of SHGs may lose their motivation and the sustainability of the micro enterprises may be affected in the long run.

\section{Conclusion:}

SKDRDP play a vital role in helping rural women to form Self-Help Groups and they motivated women to join Self-Help Groups. Nearly 52\% of the respondents informed that Non-governmental Organisations helped them to form Self-Help Groups. Government departments and neighboring Self-Help Groups play very negligible role in the formation of Self-Help Groups. It is concluded that NGOs and self motivation of women are the main motivational factors to join SHGs and Self-Help Group members also influence other women to join the groups. Respondents are well aware about the role of SKDRDP where SKDRDP are active in their quality of work rather than the no of players and is reflected in the study. It is concluded that SKDRDP play an important role in SHG formation, linking the groups with the banks, arranging for loans and imparting training to start income generating activities

\section{References:}

[1] Ahmad, Mokbul Morshed (2006), 'The NGO Debate in Development: A Review' in M.C.Behra (ed),Globalising Rural Development, Sage Publications, New Delhi.

[2] APMAS (2009), "Report on Situation Analysis of Self-Help Group Movement in Bihar".: APMAS,Hyderabad.

[3] Basu, Priya and PradeepSrivastava (2005), 'Exploring Possibilities Microfinance and Rural CreditAccess for the Poor in India', Economic and Political Weekly .Vol 40(17): pp1747 - 1756.

[4] Ghosh. D.K. (2005), 'Intervention in Poverty Alleviation-Scope and Reality' in S.B. Verma and Y.T.Pawar (Eds), Rural Empowerment through SHGs, NGOs and PRIs), Deep \& Deep Publications, New Delhi

[5] Dadhie C.L. (2001), "Micro finance - a panacea for poverty alleviation - A case study of oriental Grameena Project in India.

[6] Harper, Malcolm (2002), 'Promotion of Self-Help Groups under the SHG Bank Linkage Programme in India', NABARD,Mumbai

[7] Joel S.G.R (.2003), 'NGOS and Rural Development', Concept Publishing Company, New Delhi

[8] Khandakar Q. Elahi and Constantine P. Danopoulos (2004) 'Microfinance and Third World Development: A Critical Analysis', Journal of Political and Military Sociology, Vol. 32, No. 1,pp 61-77.

[9] Laxmi. R. Kulashrestha and Archana Gupta (2005), 'NGO in Micro-financing: Partner in Rural Development' in S.B. Verma and Y.T. Pawar (Eds), Rural Empowerment through SHGs, (NGOs andPRIs), Deep \& Deep Publications New Delhi 
[10] Loyola (2004), 'A Comparative Study of Self-Help Groups (SHGs) Organised and Promoted by NongovernmentalOrganisations (NGOs) and Kudumbashree - A Government Organised NongovernmentalOrganisation (GoNGO) in Kerala towards Empowerment of Poor Women, LoyolaExtension Services, Thiruvananthapuram.

[11] Manimekalai, M. Rajeshwari, G. (2001), 'Nature and Performance of Informal Self-Help Groups - ACase from Tamil Nadu, Indian Journal of Agricultural Economics, Vol. 56 (3), July-Sept, 2001.

[12] Mishra, Dharmendra (2005), 'Participatory Governance through NGOs', Aalekh Publishers, Jaipur.

[13] National Council of Applied Economic Research (2008), 'Impact and Sustainability of SHG BankLinkage Programme', NCAER. New Delhi,

[14] Ramachandran, S (2007), Role of NGOs in Microfinance, in Souvenir on National Conference onSustainable Rural Development through Micro-Credit, Chidambaram, May 2007, pp38-39.

[15] Sinha, Sanjay (2007), 'Efficiency with Growth: the Emerging Face of Indian Microfinance, ADBFinance for the Poor. Volume 8, Number 3.

[16] Sinha, Frances (2007), 'Social Performance in Indian Microfinance in PrabhuGhate (Ed.), Microfinance in India: A State of the Sector Report - 2007, Microfinance India New Delhi,

[17] Shylendra, H.S. (2007): 'Microfinance Bill: Missing the Forest for the Trees', Economic and PoliticalWeekly, Vol XLII, (27-28), pp2910-2914.

[18] Thirunarayanasamy. M and S. Thirumaran (2007): 'Role of NGOs in Microfinancing', in Souvenir onNational Conference on Sustainable Rural Development through Micro-credit, Chidambaram, May2007, pp19-20.

[19] SKDRDP reports 2012-13 